\title{
The quality of water in small community supplies of Kingolwira village, Morogoro, Tanzania
}

\author{
N.B. SHAYO ${ }^{1 *}$, B.E. CHOVE ${ }^{1}$, A.B. GIDAMIS ${ }^{2}$ and O.B. NGOMA $^{1}$ \\ ${ }^{1}$ Department of Food Science \& Technology, Sokoine University of Agriculture, \\ P.O. Box 3006, Morogoro, Tanzania \\ ${ }^{2}$ African Institute for Capacity Development, P. O. Box 46179 GPO 00100 Nairobi, Kenya
}

\begin{abstract}
Water quality is an important aspect in human health, as the majority of infectious diseases that cause morbidity and mortality in population are water related. The present study was undertaken to assess the quality of water in Kingolwira, Morogoro Rural District, Tanzania. Water was collected from different sites in the village and analysed for a period of six months. Physical, chemical and microbiological qualities of water were examined. The $\mathrm{pH}$ of the water ranged from 7.02 to 7.20 and the water temperature ranged from $25.7^{\circ} \mathrm{C}$ to $27.0^{\circ} \mathrm{C}$. The total dissolved solids of the water samples ranged from 110 to $510 \mathrm{ppm}$. The water contained considerable levels of lead and copper ranging from 0.034 to $0.090 \mathrm{ppm}$ and 0.022 to $0.030 \mathrm{ppm}$, respectively. Total water hardness ranged from 19.60 to $228.10 \mathrm{ppm}$ as calcium carbonate. The total viable counts and faecal coliform counts ranged from $2.75 \times 10^{3}$ to $5.4 \times 10^{3} \mathrm{c} . \mathrm{f} . \mathrm{u} / \mathrm{ml}$ and $0.93 \times 10^{2}$ to $2.1 \times 10^{2} \mathrm{counts} / 100 \mathrm{ml}$, respectively. Overall, water supplies in the village were judged as of poor quality. Water is usually used for domestic purposes including cooking, drinking, washing and preparation of infant foods without any treatment. In conclusion therefore, water in Kingolwira village is of poor quality and needs to be treated before consumption. Theres is also a need for the rural population to be educated on hazards of using untreated water. In general, sanitary facilities in rural areas in Tanzania need to be improved in order to avoid health hazards.
\end{abstract}

Keywords: water, quality, health, Tanzania

\section{Introduction}

Water is probably the most important natural resource in the world as it plays a vital role in the development of communities. A reliable supply of water is therefore, an essential prerequisite for the establishment of a permanent community settlement. The domestic use of water is mainly influenced by various factors such as economic, physical, technological, and geographical as well as those related to culture and religion. Unfortunately the liquid and solid wastes from such a community have considerable potential for environmental pollution. In primitive civilizations the remedy for this pollution problem was simply to move the community to another suitable site. In more advanced civilizations such upheavals become impractical and measures must be taken to protect and augment water supplies and for the satisfactory disposal of waste materials.

The concept of water as a natural resource, which must be carefully managed is very important as growing populations and industrial developments demand ever-increasing supplies of water (Tebbutt, 1993). Water relates directly with the nutritional status of individual due to its important functions in the body. Human body requires minerals for its metabolism and water is a source of these minerals such as sodium, calcium and zinc (Pontius, 1994). Water quality is therefore an important aspect to observe as the majority of population in developing countries is affected by water-related diseases. Recent estimates suggest that $5-10 \%$ of deaths in these countries are due to water related diseases (Hammer \& Hammer, 2003).

Water quality refers to all attributes of water, which make it acceptable to the people. The quality criteria can generally be classified as microbiological, physical and chemical (FAO, 1993). In certain cases chemicals in water may be potential causes of diseases (Hammer \& Hammer, 2003). Water derived from different sources may greatly differ in quality. Rainwater collects impurities while passing through the air, while stream and rivers collect impurities from surface run off. Discharge of sewage and industrial wastes is carried to the rivers, ponds and springs (Bhattacharya, 1998).

Natural and treated waters vary in microbiological quality. Drinking water should be free from the pathogenic microorganisms as well as chemical contaminations, which may be hazardous to health. All supplies of water are required to be as pleasant to drink as circumstances permit. The construction, operation, supervision of water supply reservoirs and distribution system should exclude any possible pollution of the water (TBS, 1997). Water pollution is caused by many factors, which as a result favour the growth of microorganisms and increase level of toxic minerals and inorganic compounds, which 
directly affects health of a population. Agricultural activities near water sources may also introduce heavy metals and organic compounds through the use of fertilizers, pesticides and animal manure. Polluted water can be used to irrigate gardens and in so doing this creates health hazards for those who are mostly using these agricultural products (Hammer \& Hammer, 2003). Data on water quality in various rural areas of Tanzania is not available. The present study was therefore carried out to examine some aspects of water quality and how they affect nutrition and health of the population in a village.

\section{Materials and Methods}

\section{Study area}

Kingolwira ward is located in Morogoro Urban District in Tanzania. It has an estimated population of over 10,653 people of which $36 \%$ are children below 15 years of age (URT, 2005). The main sources of water in the village are through taps, wells, river and water reservoirs or dams. The occupation of the population is mainly farming activities.

\section{Water sampling}

Water samples were collected twice per month from three selected sampling sites of Kingolwira villages as representative of water supply in the distribution systems over a period of six months commencing from January to June, 2004. These sites were Magereza, Sisal Industry and Railway Station. Sampling procedures were done according to the standard procedures as described by Harrigan \& McCance (1976) using sterile bottles. At Kingolwira Railway Station the samples were collected from the public taps originating from river Pangawe. At Magereza and Sisal Industry, samples were collected from water reservoirs where the inhabitants obtained water. The samples were analysed in the laboratory at the Department of Food Science and Technology, Sokoine University of Agriculture in Morogoro and Coca-Cola Kwanza Ltd. laboratory, Dar es Salaam, Tanzania in order to authenticate the results.

\section{Determination of biochemical oxygen demand}

The water biochemical oxygen demand (BOD) was determined using the technique described by Hammer $\&$ Hammer (2003). An amount of $500 \mathrm{~g}$ of $\mathrm{NaOH}$ and $135 \mathrm{~g}$ of $\mathrm{NaCl}_{2}$ were dissolved in water and diluted to $950 \mathrm{ml}$ and then cooled. Slowly, with stirring, a solution of $10 \mathrm{~g}$ of sodium azide $\left(\mathrm{NaN}_{3}\right)$ in $40 \mathrm{ml}$ of water was added. Then the solution was stored in dark bottle with rubber stopper. To $4 \mathrm{ml}$ of the solution prepared above, $1 \mathrm{ml} \mathrm{MnSO}_{4}$ was added and mixed well and gently. The precipitates formed were allowed to settle and $5 \mathrm{ml}$ concentrated $\mathrm{HCl}$ was added, stoppered and mixed well. From the liquid $25 \mathrm{ml}$ was taken and titrated with $1 \mathrm{~N} / 80 \mathrm{Na}_{2} \mathrm{~S}_{2} \mathrm{O}_{3}$ using starch indicator. The process was repeated after 5 days. The same water was incubated at $20^{\circ} \mathrm{C}$ for 5 days.

The intermediate ppm was calculated using the formula:

$$
\text { Intermediate } \mathrm{ppm}=\frac{\text { Titration } \times 20}{\text { Titre }(\text { Volume of bottle })}
$$

Then: (intermediate ppm -5 days ppm) $\mathrm{x}$ dilution $=\mathrm{BOD}$ in $\mathrm{ppm}$

Dilution 1:75 (1ml of sampled $\mathrm{H}_{2} \mathrm{O}+24$ hrs distilled water). During this experiment a pinch of sodium carbonate was added to eliminate $\mathrm{CO}_{2}$.

\section{pH of water}

The water $\mathrm{pH}$ was determined by potential metric method using a pH-meter-EEL Model 7. A buffer of pH 7.0 was prepared to calibrate the meter before measuring the $\mathrm{pH}$ (Hammer \& Hammer, 2003). The electrode of the $\mathrm{pH}$-meter was thus dipped into water samples and the $\mathrm{pH}$ reading was recorded directly.

\section{Turbidity}

A bottle (1litre) was filled with the water under examination and the sample was compared with a similar bottle of distilled water containing $1 \mathrm{~g}$ of diatomous earth. Before the sample was compared, the later bottle and its content were agitated from time to time for an hour and left to stand for $24 \mathrm{hrs}$. Then with the aid of a ruler, measurements were taken and the turbidity reported in terms of units (Hammer \& Hammer, 2003).

\section{Water hardness and mineral contents}

Permanent hardness was determined by using the method described by (Hammer \& Hammer, 2003). Two conical flasks were used one with $200 \mathrm{ml}$ of water sample and the other containing $200 \mathrm{ml}$ of distilled water were used to boil water for about 15 minutes so as to expel $\mathrm{CO}_{2}$. Then $25 \mathrm{ml} 0.1 \mathrm{M} \mathrm{NaOH}$ and $25 \mathrm{ml} .0 .005 \mathrm{M} \mathrm{Na}_{2} \mathrm{CO}_{3}$ solutions were added, mixed thoroughly and boiled until the volume reached $120 \mathrm{ml}$. The samples were cooled and transferred into $200 \mathrm{ml}$ volumetric flask. The samples were then filtered and titrated with $0.05 \mathrm{M} \mathrm{H}_{2} \mathrm{SO}_{4}$ using methyl orange as indicator. For each sample, blank titre was obtained. 
The permanent hardness was obtained by using the following formula.

( $\mathrm{ml}$ of blank titre-ml of sample titre)

Ppm $\mathrm{CaCO} 3=\frac{\text { Volume }(\mathrm{ml}) \text { sampletaken }}{\mathrm{x}} \times 0.005 \times 1000000$

Temporary hardness was determined by titrating 200 $\mathrm{ml}$ of water sample with $0.05 \mathrm{M} \mathrm{H}_{2} \mathrm{SO}_{4}$ using methyl orange as an indicator.

$$
\text { Ppm CaCO3 }=\frac{\text { Titre } \mathrm{x} 0.005 \times 1000000}{\text { Volume }(\mathrm{ml}) \text { of sample taken }}
$$$$
1 \mathrm{ml} 0.05 \mathrm{M} \mathrm{H}_{2} \mathrm{SO}_{4}=0.005 \mathrm{~g} \mathrm{CaCO}_{3}
$$

Total hardness $=$ permanent + temporary hardness.

Chloride in the samples was analysed by the method described by Swarup et al., (1992). The samples were titrated with silver nitrate using potassium chromate as an indicator. Blank titre was obtained for each sample and chloride was calculated using the following formula:

The water samples were prepared and analysed for presence of lead and copper using Atomic Absorption Spectrophotometer as described by Swarup, et al., (1992). The temperature of the water was recorded directly on the sites by using thermometer (APHA,

$\underline{\mathrm{Mg} \text { of } \mathrm{CI}=(\mathrm{ml} \text { of sample titre }-\mathrm{ml} \text { of blank titre) } \mathrm{x} \text { Normality of AfNO3 } \times 35.46 \times 100}$ Volume (ml) of sample

1985). Total Dissolved solids (TDS) in the water samples were measured and recorded using Dissolved Solid meter as described by Hammer \& Hammer (2003).

\section{Microbiological examination}

A total viable count of water samples was determined as described by Harrigan \& McCance (1976). Microbial counts were determined in duplicates by using $1 \mathrm{ml}$ water samples on plate count agar (DIFCO) pour plates. Plates were incubated at $30^{\circ} \mathrm{C}$ for 3 days. The methodology adopted to enumerate the faecal coliform was presumptive test for coliform group following the Most Probable Number (MPN). Three tubes were inoculated with $1 \mathrm{ml}$ from $10^{-1}, 10^{-2}, 10^{-3}$, $10^{-4}$ and $10^{-5}$ prepared dilutions. The tubes were incubated for $48 \mathrm{hrs}$ at $37^{\circ} \mathrm{C}$. All tubes showing gas production were observed and recorded. The MPN tables for 3 tubes dilution were used to report the result of the presumptive MPN of coliform bacteria per $\mathrm{ml}$. of water (WHO, 1984; Harrigan \& McCance, 1976).

\section{Results}

\section{Physical and chemical characteristics of water}

The physical and chemical attributes of water are summarised in Table 1. The biological characteristics of water were based on biochemical oxygen demand (BOD) and microbiological quality of water, which included total viable counts, and faecal coliform counts. The results of BOD in the sites ranged from 0.021 to $0.091 \mathrm{ppm}$ (Table 2).

\section{Discussion}

The $\mathrm{pH}$ of the water ranged from 7.02 to 7.20 while according to Hammer and Hammer, (2003), the $\mathrm{pH}$ of drinking water ranged from 6.5 to 8.3. The results indicate that the $\mathrm{pH}$ of the water in three sites is within

Table 1: Average value of physical and chemical attributes of water quality in Kingolwira

\begin{tabular}{lllll}
\hline Attribute & Units & Magereza & Railway Station & Sisal Industry \\
\hline Temperature & $\ldots \mathrm{C}$ & 26.2 & 25.7 & 27.0 \\
Alkalinity/acidity & $\mathrm{pH}$ & 7.10 & 7.02 & 7.20 \\
TDS & $\mathrm{ppm}$ & 500 & 110 & 7.20 \\
Chlorides & $\mathrm{mg} / \mathrm{l}$ & 0.029 & 0.213 & 0.100 \\
Lead & $\mathrm{ppm}$ & 0.064 & 0.090 & 0.034 \\
Copper & $\mathrm{ppm}$ & 0.025 & 0.030 & 0.022 \\
Turbidity & INTU & $<\mathrm{INTU}$ & $<$ INTU & $<$ INTU \\
Hardness (Total) & $\mathrm{ppm}$ as CaCo & 124.13 & 19.60 & 218.10 \\
\hline
\end{tabular}

Key: INTU=1 mg/1; ppm= parts per million 
Table 2: Biochemical oxygen demand and microbial counts (c.f.u/ml) in water supplies in Kingolwira

\begin{tabular}{lccc}
\hline Site & $\begin{array}{c}\text { Total } \\
\text { counts } \\
\text { (c.f.u/ml.) }\end{array}$ & $\begin{array}{c}\text { Viable Faecal } \\
\text { coliform } \\
\text { counts } / 100 \mathrm{ml}^{*}\end{array}$ & BOD $(\mathrm{ppm})^{*}$ \\
\hline Magereza & $5.0 \pm 0.63 \times 10^{3}$ & $1.5 \pm 0.35 \times 10^{2}$ & 0.021 \\
Railway Station & $5.4 \pm 0.66 \times 10^{3}$ & $2.1 \pm 0.41 \times 10^{2}$ & 0.091 \\
Sisal Industry & $2.75 \pm 0.55 \times 10^{3}$ & $0.93 \pm 0.27 \times 10^{2}$ & 0.050 \\
\hline
\end{tabular}

* Mean microbial counts and BOD of 24 samples from each site over a six-month period

the range. Total dissolved solids (TDS) ranged from (110 to 510) ppm. TDS for site A and B are within the range, but site $\mathrm{C}$ is out of range, this is due to certain substances from the Kingolwira Sisal Industry that dissolve in the water. An upper limit of 500 ppm has been set in order to control undesirable taste and diarrhoeal diseases (Hammer \& Hammer, 2003). Temperature increases from site $\mathrm{B}$ to site $\mathrm{A}$ and then site $\mathrm{C}$. This temperature increase may be due to the influx of effluents/discharges from the industries and agricultural wastes. The turbidity of water was found to be less than 1NTU in all the three sites. The present primary drinking water standard for turbidity is 1 NTU (Moss, 1989). Therefore all the turbidity results are within the required level of turbidity in drinking water standard.

Water from all three sites was clear and no any offensive smell detected and therefore, meets the WHO (1984), drinking water requirements. Lead from the three sites ranged from 0.034 to $0.090 \mathrm{ppm}$ (Table 1). According to WHO (1984), lead should not exceed $0.05 \mathrm{ppm}$. From the results only water from site $\mathrm{C}$ is within the required range, but that from site $\mathrm{A}$ and $\mathrm{B}$, which was 0.064 and $0.090 \mathrm{ppm}$, respectively exceeded the recommended levels of lead. The level of copper in three sites ranged from 0.022 to 0.030 $\mathrm{ppm}$. The recommended quantity by WHO (1984) is 1.0 -ppm copper. The results are within the recommended level (Hammer \& Hammer, 2003). The chloride level detected in water samples ranged from 0.029 to $0.213 \mathrm{mg} / \mathrm{l}$. This is quite low as compared to concentration of chloride of $250 \mathrm{mg} / 1$ recommended by WHO (1984). According to Moss (1989), these small amounts of chlorides are not toxic to human health and usually results from either agricultural fields receiving fertilizers, animal wastes or industrial effluent. In respect to any concentration of chloride in the surface or ground water may be regarded as indication of faecal contamination.

The data obtained from three sites show that the total hardness of water ranged from 19.6 to 281.10 ppm as $\mathrm{CaCO}_{3}$ According to the World Health Organization (WHO, 1984) the recommended level of total hardness of drinking water is $500 \mathrm{ppm}$ as $\mathrm{CaCO}_{3}$. The results obtained are therefore lower than the recommended value indicating that water from the three sites is soft.

According to Hammer \& Hammer (2003), good river water will have a BOD of about 1 to $10 \mathrm{ppm}$ and beyond $100 \mathrm{ppm}$ is taken as contamination. A BOD of $1 \mathrm{ppm}$ is found for pure water, and $3 \mathrm{ppm}$ is considered fairly pure but BOD of $5 \mathrm{ppm}$ is the threshold value of drinking water. Therefore, the results obtained in three sites are below the limit, indicating low level of organic matter in such water. All samples of water from public taps and water reservoirs analysed were found to contain high number of micro- organisms. The public tap water had higher microbial counts than water from the reservoirs. According to these results, water supplies in the village are highly contaminated. Similar findings have been reported by Jiwa et al. (1991) in their study in the nearby Morogoro Municipality, Tanzania.

In our study, microbial analysis showed that the water contained faecal coliform ranging from $0.93 \mathrm{x}$ $10^{3}$ to $2.1 \times 10^{2} / 100 \mathrm{ml}$, which is higher than the recommended levels. According to World Health Organization guidelines for drinking water, there should not be any faecal coliform (WHO, 1984). The presence of faecal coliform indicates that water is contaminated with either animal droppings or human faeces.

The pathogenic bacteria of intestinal origin are the main concern in the water industry due to their potential to cause health hazards when ingested through drinking of water (Bhattacharya, 1988). In the village, utensils, dishes, cooking vessels and premises are washed with cold water with little or no soap or detergent. People in the village do not boil water for drinking. They take it directly from the reservoir or public taps and use it (data not shown). These pose the community to danger of contracting water related infections such as diarrhoeal diseases. Therefore, to prevent or reduce adverse health effects of water, health factors should be given adequate consideration. 
According to these findings it can be concluded that, the quality of water supply to Kingolwira village is poor and indicates potential health hazards. The primary health worker or district sanitarian should make sure that the following is practised on: Inspecting supplies of water in order to detect actual or potential contamination of water resulting from human or animal activities near the source of water supply. Human activities such as cultivating, grazing, washing clothes, taking bath and swimming in and around the source of the water should be prohibited. Public should be educated on the hazards related to untreated water and on the importance of boiling water prior to drinking. Devising method, possibly with help from the community, for protecting the water source from contamination. Providing health advice to water users on procedures that will prevent or diminish the chances of contamination of the water supply and to the containers used to store water. Periodical water analysis and treatment should form part of the routine activitities of the district council departments of water and health. Community members should be encouraged to adopt appropriate sanitation and hygiene measures including use of latrine and boiling and filtering of water before consumption.

\section{Acknowledgements}

The authors wish to thank Sokoine University of Agriculture for the financial support to carry out this study.

\section{References}

\section{APHA (1985) Standard Method for Examination of Water and Wastewater. $17^{\text {th }}$ Edition. American Public Health Organization, New York.}

Bhattacharya, S.K. (1988) Urban Domestic Water Supply in Developing Countries. CBS Publishers and Distributions, 485, Jain Bhawan, Bhola nath Nagar Shandara, Dehli-110032, India.

FAO (1993) Prevention of Water Pollution by Agriculture and Related Activities.

Hammer, M.J. \& Hammer, M.Jr. (2003) Water and Wastewater Technology. Prentice-Hall of India. New Delhi.

Harrigan, W.F. \& McCance, M.E. (1976) Laboratory Methods is Foods and Dairy Microbiology. Academy Press, London 225-230.

Jiwa, S.F.H., Mugula, J.K. \& Msangi, M.J. (1991) Bacteriological quality of potable water supplying Morogoro Municipality and its outskirts: a case study in Tanzania. Epidemilogy and Infection 107, 479-484.

Moss, G.G. (1989) Handbook of Ground Water Development. Rscoe Moss Company Los Angeles, California.

Pontius, F.W. (1999) Water Quality and Treatment: a Handbook of Community Water Supplies. McGraw-Hill, Inc. York. $4^{\text {th }}$ Edition.

Swarup, R., Mishra, S.N. \& Janhariv, P. (1992) Environmental air Water Pollution Analysis. Mittal Publications New Delhi, India.

Tebbutt, T.A.Y. (1983) Principles of Water Quality Control. $3^{\text {rd }}$ Edition. Pergamon Press, Oxford, New York. Toronto. Sydney, Paris, Frankfurt.

TBS (1997) Tanzania Water Standard Manual. Tanzania Bureau of Standard, Dar es Salaam, Tanzania

URT (2005) 2002 Population and Housing Census. Villages and Street Statistics Morogoro Region Vol. VII. National Bureau of Statistics. Dar es Salaam, pp 135.

WHO (1984) Guidelines for Drinking Water Quality: Drinking water quality Control in Small Community Supplies. World Health Organization, Geneva. 